scientific paper, which might be the peg for an item, masks an exciting development. Equally, of course, Ford has scope to comment about developments, such as the 'test tube baby' story, where exciting publicity has masked the reality of a small and cautious scientific step, forward.
Given that such a programme must, to a large extent, reflect the personal approach of presenter and producer, "Science Now" is doing a good job. It seems unfortunate, however, that it is broadcast only once a week, at a time when many would be listeners must be involved with the ritual of weekend shopping and/or sport. Although much of the same ground is covered by New Scientist or the national press, it would still be good to have a second opportunity to hear the programme, perhaps on a weekday evening.

Sally Owen

obituary

\section{Chu K'o-Chen}

Chu K'o-Chen, one of China's most distinguished scientists, Vice President of Academia Sinica, died last February at the age of 84 . When I first met him in 1944 he was President of Chekiang University, then in exile in the little town of Mei-t'an in Kweichow Province. One could soon glimpse the qualities which endeared him to genertion after generation of Chinese scientists-a real lover of the things of the intellect and of Nature-small of stature, kindly, judicious and compassionate.

His original training in geography, meteorology and astronomy was gained at the University of Illinois in 1917 and subsequently at Harvard. After he returned to China he became Director of the National Meteorological Institute of Academia Sinica at Nanking. Later on, after the Second World War, he was called from Chekiang University to become one of the Vice Presidents of the newly reconstituted National Academy of Sciences. Apart from his early publications in geography and the techniques of meteorology, he acquired a life-long interest in phenology (historical meteorology). Thus it came about that Chu K'o-Chen led a whole group of scientists in the study and analysis of China's climatic changes over more than 5,000 years.

Another great interest of Chu K'oChen was the history of astronomy in Chinese culture. He published a number of papers on such subjects as the origin of the twenty-eight lunar manshions $(h s i u)$ and the development of calendrical science. It was natural, therefore, that he should exercise a beneficial influence on such studies in China, and he was one of the founders of the Institute of the History of Science some years ago in Peking, where it occupies the lovely old buildings of a former Manchu prince's palace.

Many Western scientists who have worked in China have been greatly indebted to Chu K'o-Chen for his kindly understanding and never failing help. Two pictorial reminiscences of him come especially to my mind. First at Ts'un-yi, giving a warm welcome to some wandering European scientists in 1944 with the aid of the delicious pao$t z u$ (stuffed dumplings) made in that place and cooked traditionally on beds of pine needles. Secondly, at the International Congress of the History of Science at Florence in 1956, Chu K'oChen led a distinguished Chinese delegation. When we all went out to Vinci to pay our respects at the farm where Leonardo was born, and to visit the castle of the little town with its museum of Leonardo's inventions, we, as an international convention, received an unexpectedly enthusiastic welcome from the podestà and the people of Vinci. They regaled us with a splendid lunch and with an al fresco supper where they pressed upon us flasks of the excellent local wine. The Chinese and Japanese delegates, having come from so far away to pay homage to Leonardo, were particularly appreciated by the cittadini, and the sight of Chu K'o-Chen and his colleagues leaving for the bus with as many flasks as they could possibly carry remains one of my happiest recollections in the world of international science and its history.

\section{Announcements}

\section{Awards}

Alasdair Muir Breckenridge has been awarded the Paul Martini Award 1974 by the Medizinisch Pharmazeutische Studiengesellschaft eV, Frankfurt.

Chaim Leib Pekeris has been awarded the 1974 Vetlesen Prize in Earth Sciences by the University of Columbia.

\section{Appointments}

Bernard Salvage has been appointed to a personal chair of high voltage engineering at Heriot-Watt University.

W. A. Cramond has been appointed Principal and Vice-Chancellor of the University of Stirling.

\section{Errata}

In the article "Elongation factors for chloroplast and mitochondrial protein synthesis in Chlorella vulgaris" by $O$. Ciferri and $O$. Tiboni (Nature new Biol., 245, 209; 1973) some of the references in the text were wrongly numbered. The following corrections should be made: in Table 1 and Fig. 1, 3 should be $6 ; 4,7 ; 5,8 ; 6,9 ; 7,10$; in Fig. 2, 9 should be 12; in the text on pages 210 and 211,10 should be $13 ; 11,14 ; 12,15 ; 13,16 ; 14,17$; 15,$18 ; 16,19 ; 17,20 ; 18,21$; and $19,22$.

In the article "Dietary preference and diseases of age" by M. H. Ross and G. Bras (Nature, 250, 263; 1974) an error appeared in Table 1. The third number down in the penultimate column should read $77^{\prime \prime}$ not $7^{\prime \prime}$.

\section{Corrigenda}

In the article "Early visual adaptation in goldfish retinal ganglion cells" by $\mathrm{A}$. J. Afanador and A. J. Adams (Nature, 250,$346 ; 1974$ ) the last line of the legend to Fig. 2 should read " 0 corresponds to $7.2 \times 10^{15} \mathrm{~s}^{-1} \mathrm{~cm}^{-2 n}$.

The following corrections should be made to the article "Platelet contractile regulation in an isometric system" by I. Cohen and A. de Vries (Nature, 246, 36; 1973); line 41, $0.2 \mathrm{~g} \mathrm{~min}^{-1}$ $\mathrm{cm}^{-2}$; line $43,1.8 \mathrm{~g} \mathrm{~cm}^{-2}$; Fig. 1 ". . expressed in $\mathrm{g} \mathrm{cm}^{-2} "$; Fig. 2 ordinate Tension $\left(\mathrm{g} \mathrm{cm}^{-2}\right)$ legend, “. . expressed in $\mathrm{g} \mathrm{cm}^{-2}$ "; Fig. 2 ordinate Tension $\left(\mathrm{g} \mathrm{cm}^{-2}\right)$; Fig. 4 legend, Clot contraction model. 